\title{
SOME OBSERVATIONS ON THE CLIMATE OF LEWIS GLACIER, MOUNT KENYA, DURING THE RAINY SEASON
}

\author{
By C. M. Platt \\ (Department of Physics, Queen Mary College, London, England)*
}

\begin{abstract}
Meteorological observations were made on Lewis Glacier, Mount Kenya, during the "long rains" in April I96o. General meteorological observations indicated rather similar conditions to those found in other months. Ablation occurred on each day but amounts were generally small. Rather more accumulation occurred than is expected during the dry season, but again amounts were small. The net accumulation over a Io day period was only $0.38 \mathrm{~cm}$. water-equivalent, although about $30 \mathrm{~cm}$. new snow (about $\mathrm{ro} \mathrm{cm}$. waterequivalent) was lying when the expedition arrived. Detailed observations of short-wave radiation, temperature, wind and humidity with estimates of long-wave radiation were used to calculate the heat balance at the surface of the upper ablation region. Agreement between calculated and measured ablation was reasonably good. Over the periods considered, radiation accounted for $89 \cdot 5$ per cent of ablation, turbulent exchange from the air for 8.0 per cent and evaporation for 2.5 per cent. Sub-surface melting was taken into account and the formation of ice bands in terms of such melting is discussed.
\end{abstract}

RÉsumÉ. Quelques observations du climat du Lewis Glacier, Mount Kenya, pendant la saison des pluies. Des observations météorologiques ont été effectuées au Lewis Glacier, Mount Kenya, pendant les grandes pluies d'avril I960. Les observations météorologiques générales montrent des conditions analogues à celles des autres mois. L'ablation avait lieu chaque jour, mais ses valeurs étaient généralement faibles. L'accumulation était plutôt forte comparativement à celle attendue pour la saison sèche, mais ses valeurs aussi étaient faibles. L'accumulation nette pendant une période de ro jours était seulement d'une valeur en eau de o, $38 \mathrm{~cm}$, même si environ $30 \mathrm{~cm}$ de neige fraîche (environ ro $\mathrm{cm}$ valeur en eau) couvrait la surface à l'arrivée de l'expédition. Des observations détaillées de la radiation à courte longueur d'onde, de la température, du vent et de l'humidité, avec l'estimation de la radiation à grande longueur d'onde ont été utilisées pour calculer le bilan thermique à la surface de la zone supérieure d'ablation. L'accord entre l'ablation calculée et mesurée était raisonnablement bonne. Pour la période considérée, l'ablation était due pour $89,5 \%$ à la radiation, $8,0 \%$ à l'échange turbulent avec l'air, et $2,5 \%$ à l'évaporation. On a tenu compte de la fonte sous la surface de la neige, et la formation de strates de glace par suite de cette fonte est discutée.

Zusammenfassung. Einige Beobachtungen über das Klima am Lewis Glacier, Mount Kenya, während der Regenzeit. Meteorologische Beobachtungen wurden am Lewis Glacier, Mount Kenya, während der "langen Regen" im April 1960 angestellt. Aus allgemeinen meteorologischen Beobachtungen ergaben sich Verhältnisse, die denen in anderen Monaten ziemlich ähnlich sind. Ablation trat täglich ein, doch im allgemeinen mit kleinen Beträgen. Erheblich mehr Auftrag, als man in der Trockenzeit erwarten kann, fand statt, doch auch hier waren die Beträge klein. Die Netto-Akkumulation während einer Periode von 10 Tagen war nur $0,38 \mathrm{~cm}$ Wasserwert, obwohl bei der Ankunft der Expedition rund $30 \mathrm{~cm}$ Neuschnee (entsprechend rund $10 \mathrm{~cm}$ Wasserwert) lagen. Eingehende Beobachtungen der kurzwelligen Strahlung, der Temperatur, des Windes und der Feuchtigkeit wurden zusammen mit Abschätzungen der langwelligen Strahlung zu einer Berechnung des Wärmehaushalts an der Oberfläche im oberen Ablationsgebiet herangezogen. Die Übereinstimmung zwischen der berechneten und gemessenen Ablation war recht gut. Im Beobachtungszeitraum wurde die Ablation zu 89,5\% durch Strahlung, zu 8,0\% durch Wärmeaustausch mit turbulenter Luft und zu 2,5\% durch Verdunstung verursacht. Schmelzprozesse unter der Oberfläche wurden berücksichtigt; die Bildung von Eisbändern als Folge solcher Prozesse wird diskutiert.

\section{INTRODUCTION}

The Mount Kenya International Geophysical Co-operation Expedition (April r96o), led by Dr. I. S. Loupekine, was intended as a follow-up to the I.G.Y. expedition led by Dr. I. S. Loupekine in $1957-5^{8}$. This paper presents the results of the meteorological programme. The expedition is deeply indebted to Professor Gordon Manley for his guidance and support, and to the Royal Society for the allocation of a grant.

\section{General}

Glaciers persist on three equatorial African mountains, namely Kenya, Kilimanjaro and the Ruwenzori range. The main physical features of these glaciers have been studied in some detail (Spink, 1947, I949; Bergström, 1955; Charnley, 1959). All the glaciers have been observed in various stages of retreat and decay which has been greatly accelerated during the

* Previously at University College, Nairobi, Kenya. 
last $30 \mathrm{yr}$. There is, however, a paucity of meteorological data, although the climates of the surrounding regions are well known. Exceptions to this are the observations made by the I.G.Y. expedition to Mount Kenya in December 1957 and January $195^{8}$ (Charnley, I959) and those made by the British Ruwenzori Expedition in July and August 1952 (Bergström, I955). Whittow (1960) has analysed the wind streams of the Ruwenzori region and related them to the known accumulation and ablation seasons. Whittow and others ( 1963 ) have given some temperature and radiation measurements and commented on the apparent correlation of melting with intense insolation.

One of the outstanding problems remaining in our knowledge of the equatorial glaciers is the role played by radiation and meteorological agents, respectively, in the heat balance and ablation of the glaciers. No analysis was made by either of the above-mentioned expeditions. Bergström has remarked, however, that meteorological factors apparently play a minor part and Whittow has come to a similar conclusion. He based his findings on the apparent increase of ablation above a certain height in the Ruwenzori range, which is contradictory to findings on glaciers at other latitudes. The cause is less cloud on the higher slopes and hence increased radiation. Spink (1947, p. 334-35) has stressed the apparently decisive influence of radiation on the rapid retreat of the Kilimanjaro glaciers.

In South America, Howell (r953) worked on a glacier in the Nevado de Huagaruancha (lat. $10^{\circ} \mathrm{S}$.). He related the melt to the duration of sunshine and concluded that ablation was almost totally due to radiation.

There is an extensive literature on the heat balance of glaciers in higher latitudes, and it is clear from this that the relative importance to ablation of the different agents is dependent on the season, the mean altitude of the glacier and the situation on the glacier. Thus, turbulent exchange from the air will be an important source in high summer, on low-altitude glaciers and on the lower levels of these glaciers. Conversely, radiation plays the dominant role in spring, and on the higher levels of a glacier where the air is below freezing point. Wallén (1948) has given a good account of seasonal variations on both alpine and high-latitude glaciers, and Adkins (1958, p. 204) has summarized conditions obtaining at different latitudes. These findings appear to support the claim that on high-altitude glaciers near the Equator radiation is the dominant factor causing ablation. However, the position of any glacier snout must be determined to a great extent by its ability to survive the increasingly warm meteorological environment. It is to be expected, therefore, that even on equatorial glaciers, the lower regions of the glaciers will be affected by meteorological factors even although they are not exposed to extreme summer conditions. It is shown in this paper that this appears to be the case on Lewis Glacier.

The role of evaporation on the ablation of high mountain glaciers in low-latitude regions has also given rise to much discussion. Sharp (I95I) has stated that in the Sierra Nevada, California, at a height of $\mathrm{I} 2,000 \mathrm{ft}$. (3,700 m.) only i per cent of a snow slope was evaporated but Church (1953) has concluded that more than half the melt water at these altitudes is evaporated. Lliboutry (1954, p. 332-33) has observed that varying amounts of material are evaporated or sublimed and that a good deal of melt water disappears in this way. Several studies have been made on the role of evaporation on high-latitude, low-altitude glaciers (Sverdrup, 1935; Wallén, I948), and it is clear that evaporation is controlled by prevailing meteorological conditions. Both of these authors found that generally condensation far exceeded evaporation during the ablation season. It is shown in this paper that evaporation on Lewis Glacier is more prevalent than condensation but it acts more as an inhibiting agent to ablation rather than an agent of ablation itself. The most striking attribute of intense radiation, coupled with low temperatures and the controlling action of evaporation, is the formation of penitentes or sun pits (Matthes, I934). Several other workers have also discussed these peculiar formations and the necessary conditions for their growth. They only occur at high altitudes, although they have been observed on mid-latitude glaciers (Matthes, I934; 
Odell, I94I; Lliboutry, 1954). On the East African glaciers, they have been observed on Kilimanjaro but not on Mount Kenya or the Ruwenzori (Spink, I947, p. 334-36). Small sun cups have been observed on Mount Kenya but they do not grow to any appreciable size. Penitentes require for their growth a high rate of evaporation, intense insolation, low air temperatures and calm weather. From the analysis of the heat balance given in this paper, evaporation does not appear to be sufficient on Mount Kenya because of rather moist air streams, nor are there enough periods of prolonged sunshine. Very similar conditions are known to exist on the Ruwenzori (Bergström, I955) but conditions on Kilimanjaro are somewhat different. The glaciers are some 2,000-3, ooo ft. (6I $10-9 \mathrm{I} 5 \mathrm{~m}$.) higher than those on the other two mountains. The ice fields often protrude above the cloud belt, at least on the eastern slopes (Spink, I947, p. 277), and the air is generally cold and dry. A proposed mechanism for initial penitente formation due to local collapse of the snow surface is given in this paper.

The purpose of the r 960 expedition was to study meteorological conditions in some detail on the upper firn field of Lewis Glacier (Figs. I and 2), and attempt to relate them to measured ablation. The findings would be relevant to conditions obtaining on other equatorial glaciers.

The choice of Lewis Glacier was due mainly to the large amount of glaciological work that had already been done on this glacier; it is also reasonably accessible. The expedition further decided to study the glacier during the wettest month in the so-called "long-rains" period.

The main climatic features of the area are well known. There are two rainy seasons annually: the "long rains" of March to May and the "short rains" of November and December. The latter are often the heavier of the two in the Mount Kenya region. There is a secondary maximum on the north-western slopes during July and August. In between seasons the weather is usually dry. On the mountain itself, due to the formation of diurnal cloud round the peaks throughout the year, light snow or hail can occur in any month (Reid, 1959). Further, as the findings of the expedition show, ablation does not cease during the accumulation season. All that can be said is that the rainy seasons are periods when the accumulation usually, but not always, exceeds ablation. Over the period of the present expedition there was actually only a small net accumulation. It was, however, a poor rainy season in surrounding districts.

Mean monthly temperatures and winds at a height of $\mathrm{r} 6$, ooo $\mathrm{ft} .(4,880 \mathrm{~m}$.) over Nairobi about roo miles ( $160 \mathrm{~km}$.) south of Mount Kenya are shown in Figures $3 \mathrm{a}$ and b (East African Meteorological Department, I 960). These figures were interpolated from radiosonde measurements made at the $5^{\circ 0}$ and $600 \mathrm{mb}$. pressure levels $(5,876$ and $4,470 \mathrm{~m}$., respectively). They are expected to be relevant to the Mount Kenya region, as the same upper easterly air stream covers both regions.

Prior to the expedition's arrival, about $30 \mathrm{~cm}$. of fresh snow had accumulated.

\section{Programme of Observations. Site of Meteorological Station}

A meteorological station was set up on the same site as the r $957-58$ I.G.Y. expedition. As a whole, the glacier slopes towards the south-west but near the centre at a height of $4,750 \mathrm{~m}$. there is a fairly level stretch, where the station was sited. All the instruments were placed here except for the Campbell-Stokes sunshine recorder, which being rather heavy, was placed on some rocks about $200 \mathrm{~m}$. south-east of the station. The site was near the top of the ablation region.

\section{General Meteorological Observations}

A Negretti and Zambra thermohygrograph recorded temperature and humidity continuously. It was housed in a standard Stevenson screen, transported in sections and assembled 


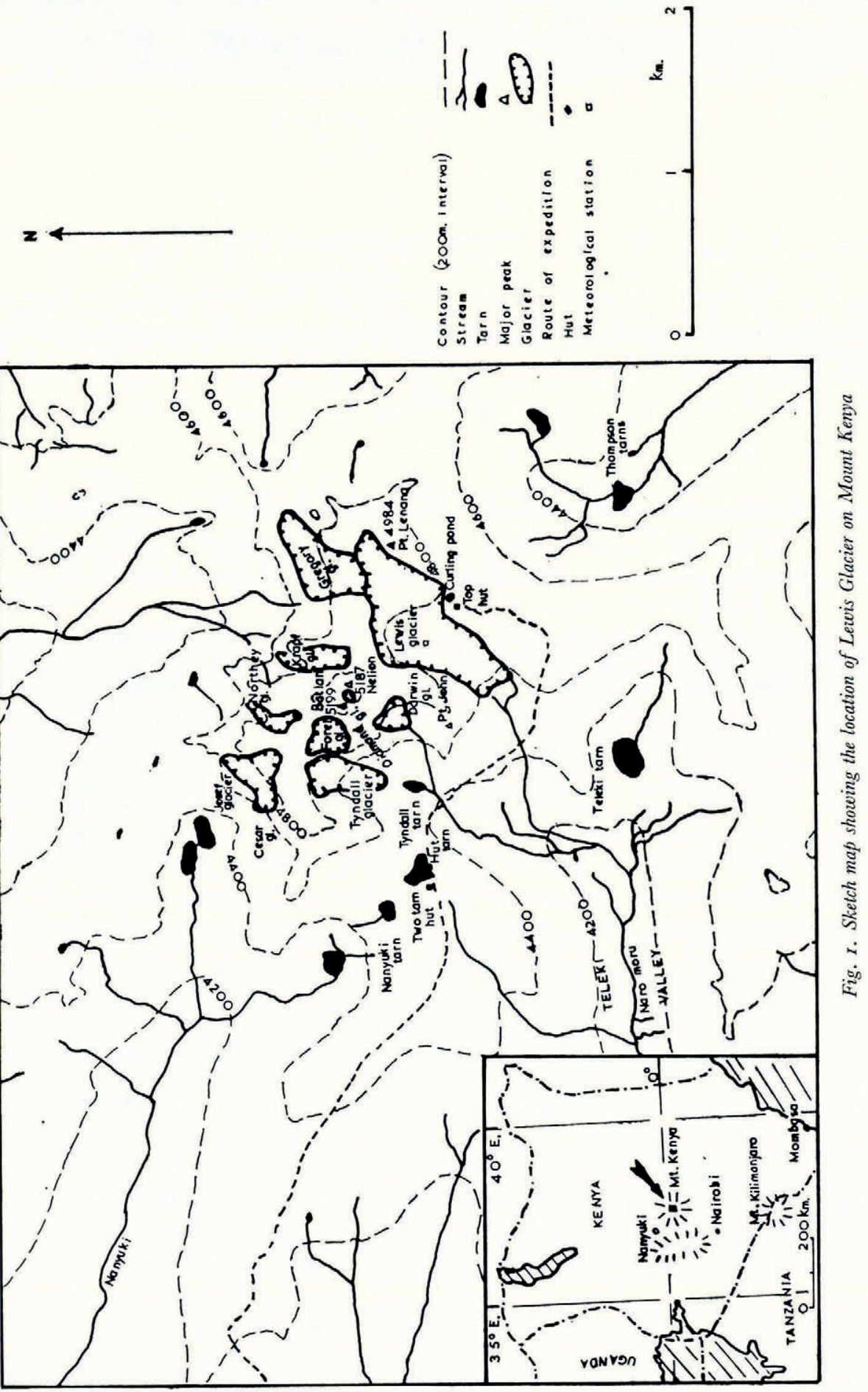




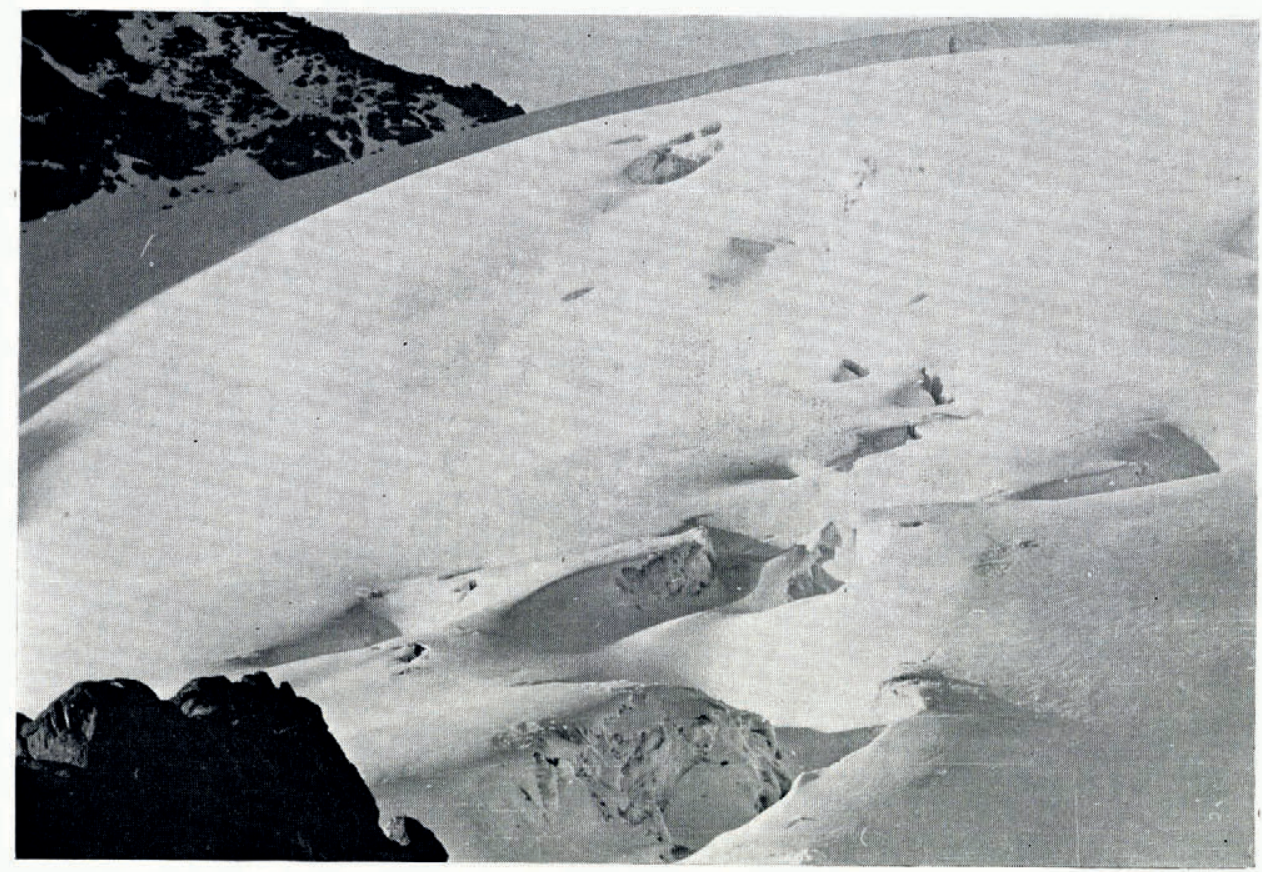

Fig. 2. Condition of Lewis Glacier at the upper firn field in April 1960

(a)

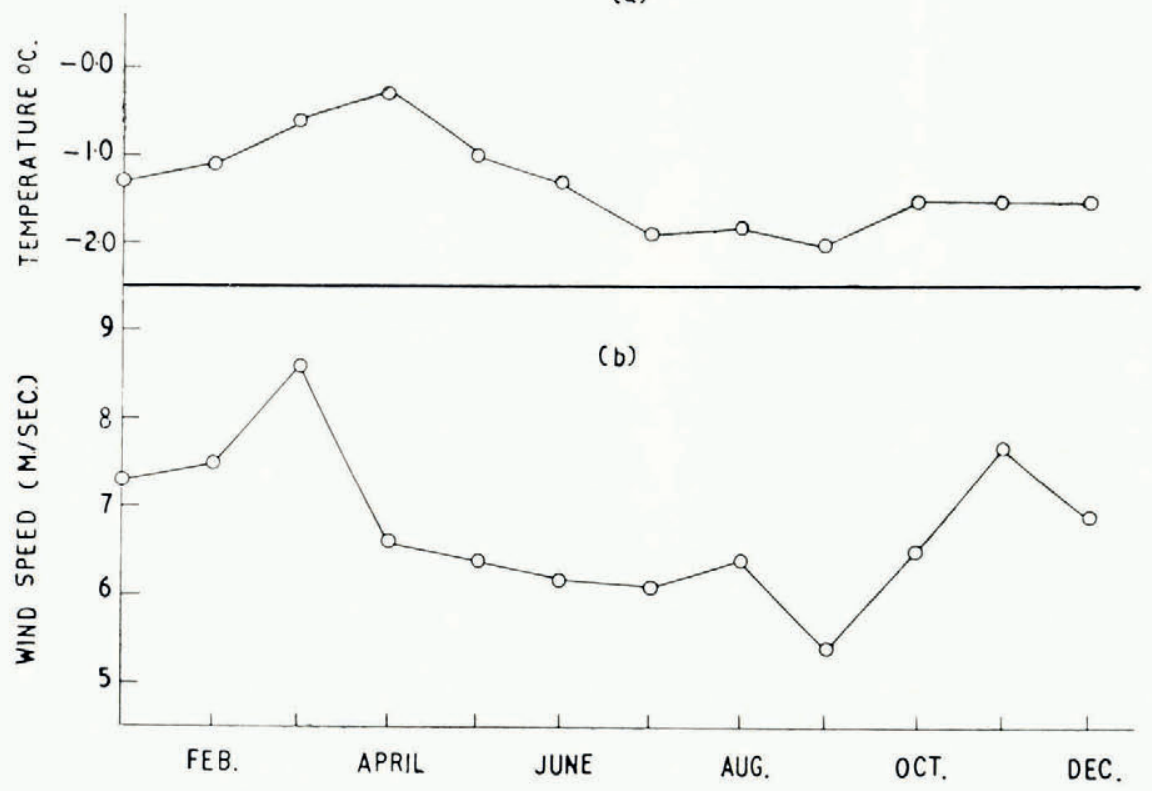

Fig. 3. Mean monthly values of temperature (a) and wind (b) at a height of 4,880 m. over Nairobi 
on the site. Aluminium foil was pasted over the roof to reduce radiation heating. Readings were checked daily against a whirling psychrometer, with which they agreed within $0 \cdot 5^{\circ} \mathrm{C}$. Records are complete for the period 2-I2 and I4 April. On I3 April the chart was lost in a strong wind. The records for 12 and 13 April are thus only partly complete but they are given to preserve continuity. As the weather was markedly similar on I3, I4 and 12 April, the errors introduced are not appreciable. Daily and hourly values of temperature, humidity and sunshine are shown in Figures $4-8$. Visual observations of weather were made four times daily at 06.00 , og.0o, 12.00 and I5.00 hr. G.M.T.

\section{Temperature Profiles near the Surface}

Temperatures at heights of $0.5,2 \cdot 0$ and $4.0 \mathrm{~m}$. above the surface were measured with Stantel type $\mathrm{GT}_{52}$ thermistors fixed to an aluminium mast (Fig. 9). They were shielded from direct radiation by aluminium boxes, open only to the north and south. The thermistor elements were mounted on aluminium strips and protected with wax. Temperatures were read on a portable Wheatstone network, which was carefully calibrated against each thermistor in situ. The circuit was similar to one used by Ward (1952, p. I 19).

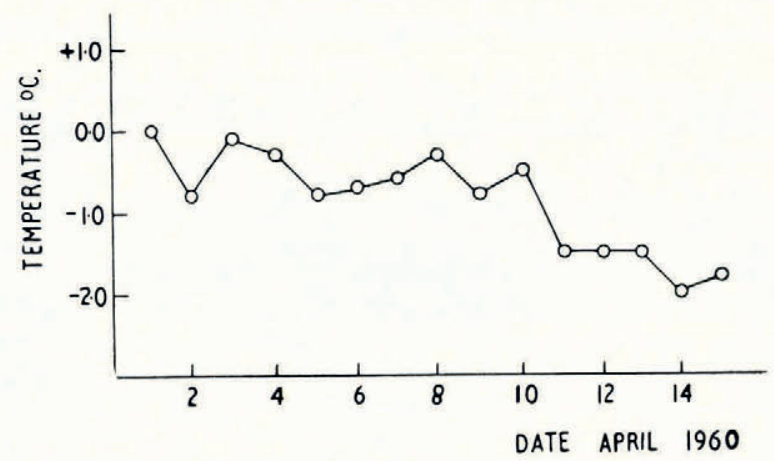

Fig. 4. Mean daily temperatures for the period ${ }_{-15}$ April 1960

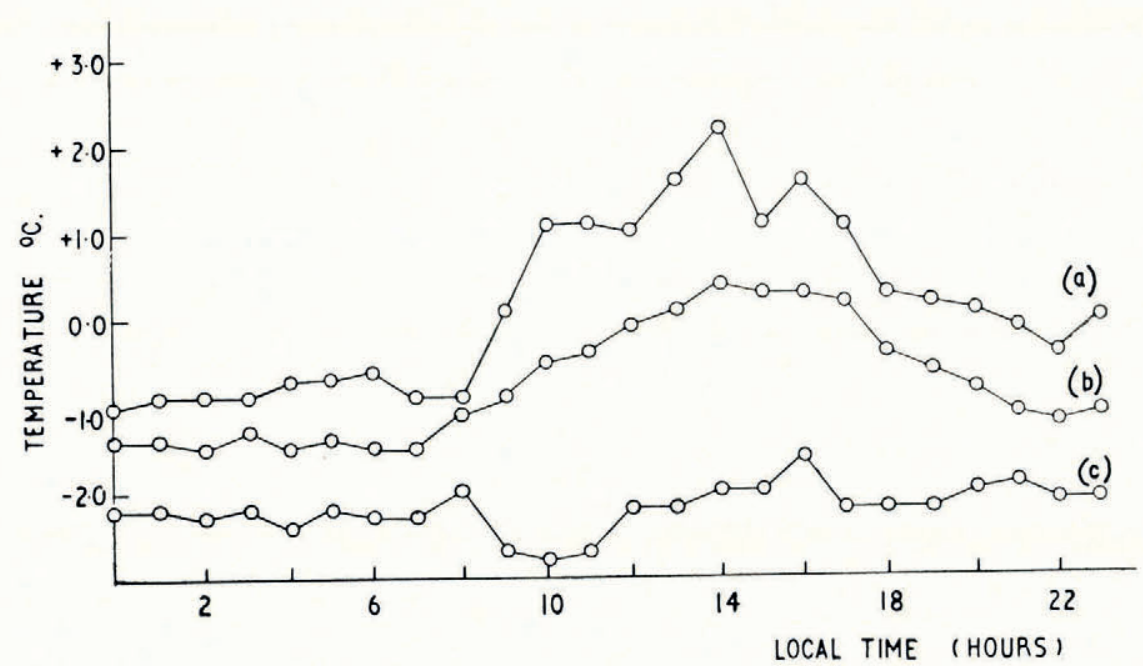

Fig. 5. Mean and extreme values of hourly temperature: $(a)$ maximum values; $(b)$ mean values; $(c)$ minimum values 


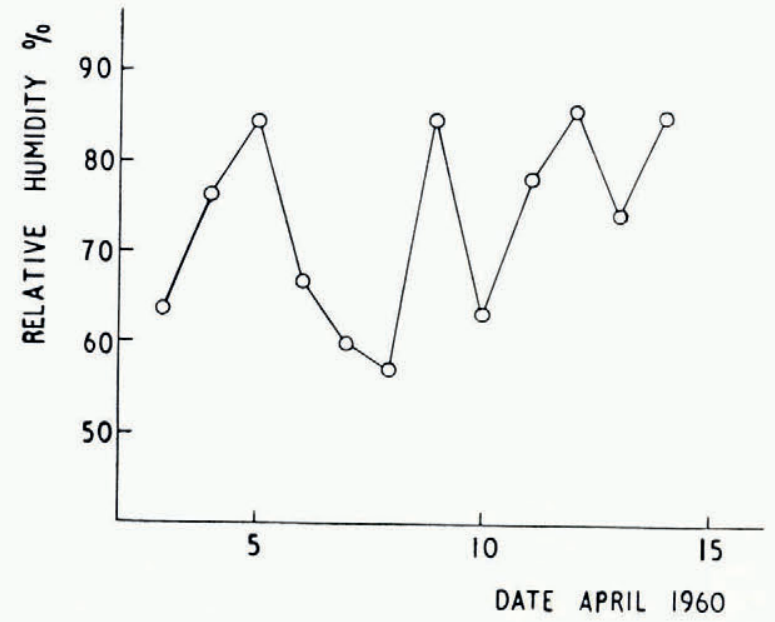

Fig. 6. Mean daily relative humidity, 3-15 April 1960

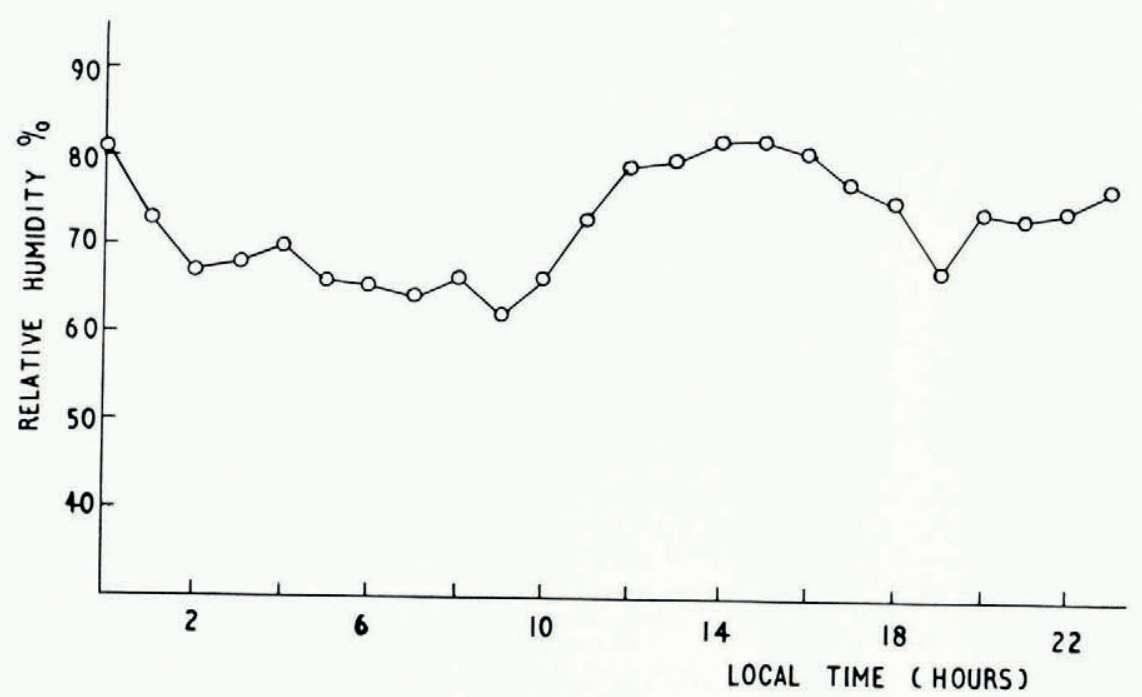

Fig. 7. Mean hourly relative humidity

Mean profiles were obtained by averaging temperatures over periods varying from 5 to $3^{0} \mathrm{~min}$. The bridge was switched to each thermistor in turn, a set of readings being obtained in about $5 \mathrm{~min}$.

During the daytime, direct radiation caused heating of the shields, which in turn caused large errors in the ambient temperature readings. Readings at $2 \mathrm{~m}$. were checked against thermograph readings at $\mathrm{I} \cdot 5 \mathrm{~m}$., with a suitable correction, and found to be several degrees Centigrade in excess during periods of strong radiation. The thermistor at $0.5 \mathrm{~m}$. was found to give the largest errors. This was expected, as the errors are sensitive to wind speed, and the wind profile above the surface is known to be approximately logarithmic. Errors were generally too high to make readings of this thermistor of any use. At 2 and $4 \mathrm{~m}$. the radiation errors are nearly equal. The difference in error can be calculated by a method similar to that used by Liljequist (1957, p. 244), who used a simple relation between the error and simultaneous wind 


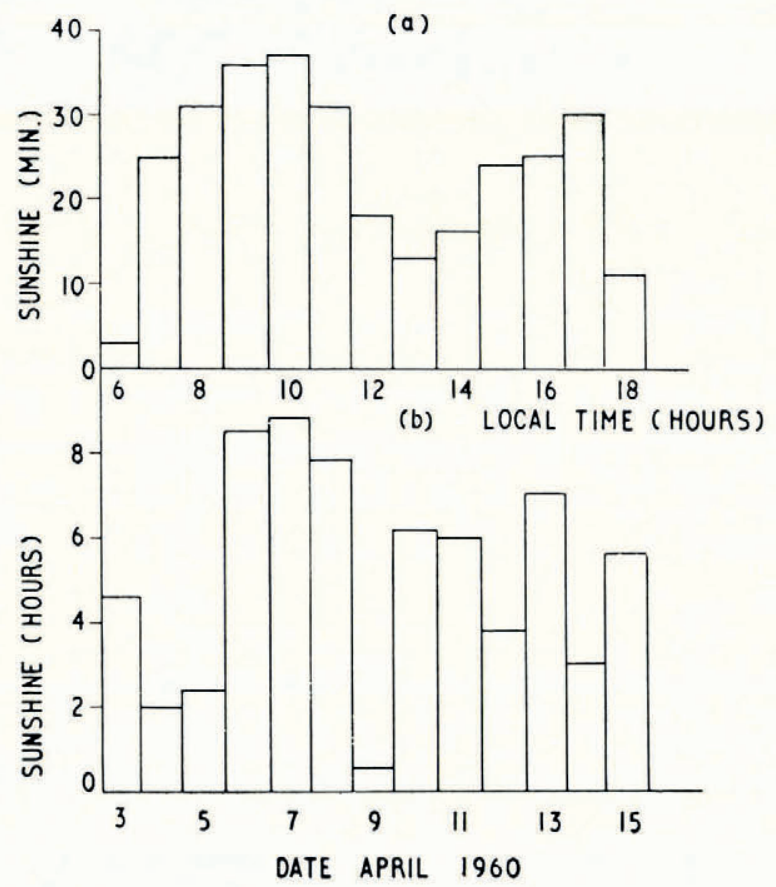

Fig. 8. (a) Duration of sunshine (min.) for each hour of the day. (b) Duration of sunshine. Daily totals for 3-15 April I96o

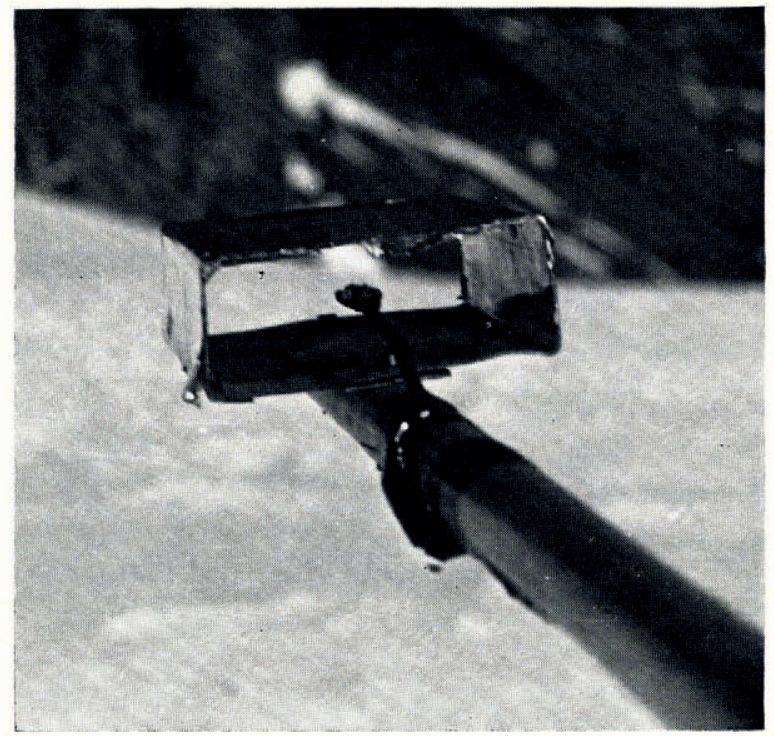

Fig. 9. Thermistor mounted in an aluminium shield 
and radiation readings. The error difference was calculated using values of temperature, radiation and wind taken at $5 \mathrm{~min}$. intervals over a period of $3 \mathrm{hr}$., and it was found to be less than $0 \cdot \mathrm{I}^{\circ} \mathrm{C}$.

For periods when the snow surface was melting, profiles were obtained subject to the following assumptions: ( $\mathrm{I}$ ) the air immediately above the snow surface is at $0.0^{\circ} \mathrm{C}$.; (2) the temperature at $2 \mathrm{~m}$. is the thermograph reading at $\mathrm{I} .5 \mathrm{~m}$. (suitably corrected); (3) the gradient between 2 and $4 \mathrm{~m}$. is the difference between the recorded thermistor temperatures.

Some typical profiles at different times of the day are illustrated in Figure ro. When the snow first melts in the morning, the air temperature is still below zero and a steep lapse in the lower layers results. By mid-day the stability is approximately neutral, and in the afternoon the air has been modified before reaching the glacier by flowing over ground which has been warmed by the sun's radiation. Thus a small inversion develops above the surface. Figure I I gives the frequencies of daytime gradients between 2 and $4 \mathrm{~m}$. It shows that the gradient is
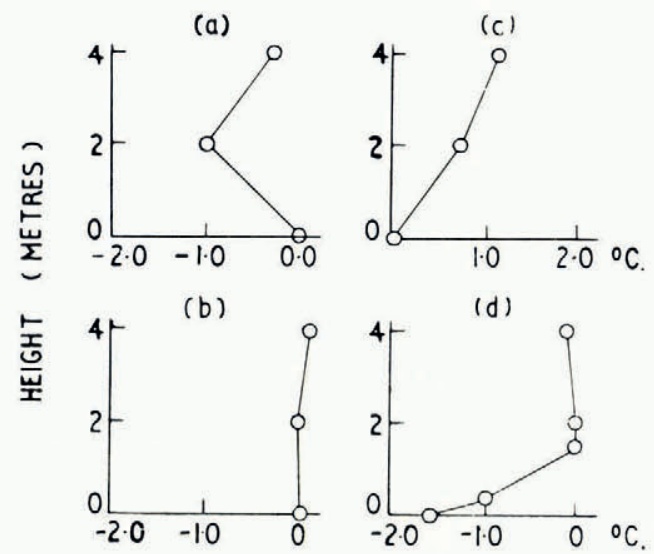

Fig. 1o. Typical temperature profiles representing different conditions

(a) $10.00 \mathrm{hr}$. (13 April 1960); (b) 12.20 hr. (5 April 1960); (c) 15.15 hr. (9April 196o); (d) 19.0o hr. (10 April 196o)

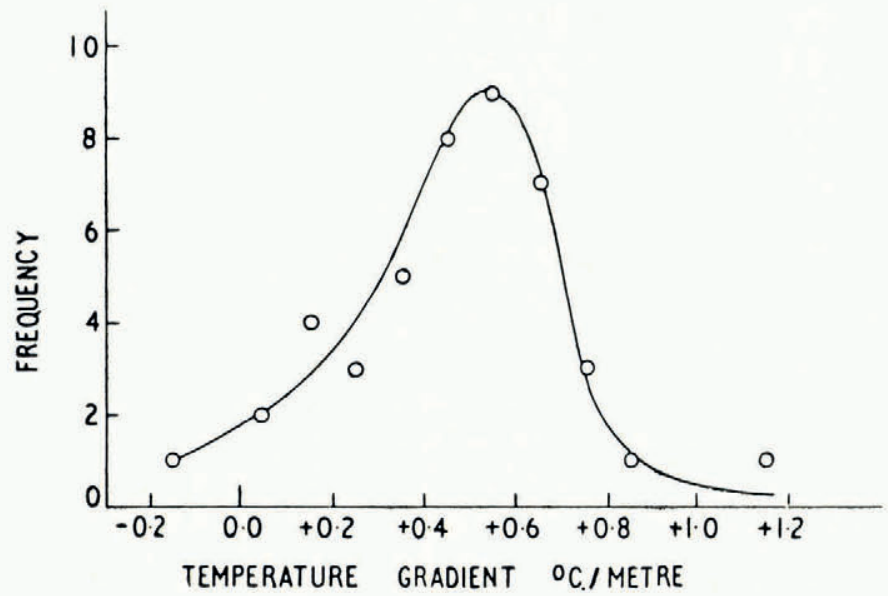

Fig. II. Frequency distribution of daytime temperature gradient between 2 and $4 \mathrm{~m}$. above the surface 
never steep, and with afternoon temperatures at about $\mathrm{I} \cdot \mathrm{O}^{\circ} \mathrm{C}$. the profiles are more nearly linear than logarithmic. It also includes morning profiles and thus shows that the lapse-rate near the surface is shallow. During the later evening periods, the thermistor shields are not subject to intense heating, and hence for these periods the temperatures at $0.5 \mathrm{~m}$. are also shown. Surface temperatures were obtained by placing an accurate mercury thermometer on the surface, with the bulb covered with a thin layer of snow. A typical profile is given in Figure rod, which shows the shallow inversion that develops rapidly near the surface when the net radiation becomes outgoing. The air cools partly by direct radiation exchange with the surface and partly from turbulent conduction. Robinson (1950) has stated that the cooling can be wholly accounted for in terms of radiation exchange; turbulent transfer probably does not set in until the inversion has become well established. The snow surface cools rapidly because the thermal diffusivity of the snow is small. The formation of a night "cold wave" in the surface layers is being investigated.

\section{Wind Measurements at Two Heights}

Wind speeds at heights of $\mathrm{I} \cdot \mathrm{Oo}$ and $2 \cdot 25 \mathrm{~m}$. were determined with two Sheppard cup anemometers supported on aluminium poles. They gave run-of-wind values which were averaged over different periods to give a mean wind strength.

Now the wind gradient at a height $z$ can be written in the form given by Deacon (quoted by Priestley (1959, p. 24))

$$
\frac{\partial u}{\partial z}=A z^{-\beta}
$$

where $\beta>\mathrm{I}$ for lapse conditions, $\beta<\mathrm{I}$ for inversions and $\beta=\mathrm{I}$ for neutral conditions. Then for neutral conditions

$$
\frac{\partial u}{\partial z}=\frac{A}{z}
$$

Integrating, and inserting suitable constants

$$
\frac{u}{u_{*}}=\frac{\mathrm{I}}{k} \ln \frac{z}{z_{0}}
$$

is obtained for aerodynamically rough flow, where $u_{*}$ is termed the friction velocity, $k$ is von Kármán's constant and $z_{0}$ is a roughness parameter. Aerodynamically rough flow would occur for velocities greater than about $0.5 \mathrm{~m}$. $/ \mathrm{sec}$. at $2.25 \mathrm{~m}$.

On the glacier, the wind is very fitful and erratic after mid-day, when it becomes light and variable. However, it was possible to calculate a value for $z_{0}$ from a period of $3 \mathrm{hr}$. when conditions were known to be neutral. The value of $0.2 \mathrm{~cm}$. obtained agrees with a figure of $0.25 \mathrm{~cm}$. obtained by Sverdrup (1936), but it is higher than the figure of $0 \cdot 10 \mathrm{~cm}$. quoted for conditions over a smooth snow surface by Priestley (I959, p. 2 I).

Due to the lack of detailed observations necessary to calculate the stability, it was not possible to ascertain values of $\beta$ for conditions other than neutral. According to values given by Deacon (quoted by Priestley (1 959, p. 24)), $\beta$ varies between $0 \cdot 7$, for very stable conditions, and $\mathrm{I} \cdot 2$, for very unstable conditions.

Figure 12 gives wind speed at $2 \cdot 25 \mathrm{~m}$. plotted against mean time of observation for all periods of observation. The generally light nature of the wind during the afternoon is clearly illustrated and is a very characteristic feature of the mountain. At this time the main air stream is replaced by convectional up-currents which reach almost to the topmost peaks. During April they were typically from the south or south-east, but they have been observed from the west in January (Charnley, I959, p. 490). Wind speeds at $\mathrm{i} 6,000 \mathrm{ft}$. (4,880 m.), measured by radiosonde at Nairobi at 03.00 and $14.00 \mathrm{hr}$. local time and covering the period 


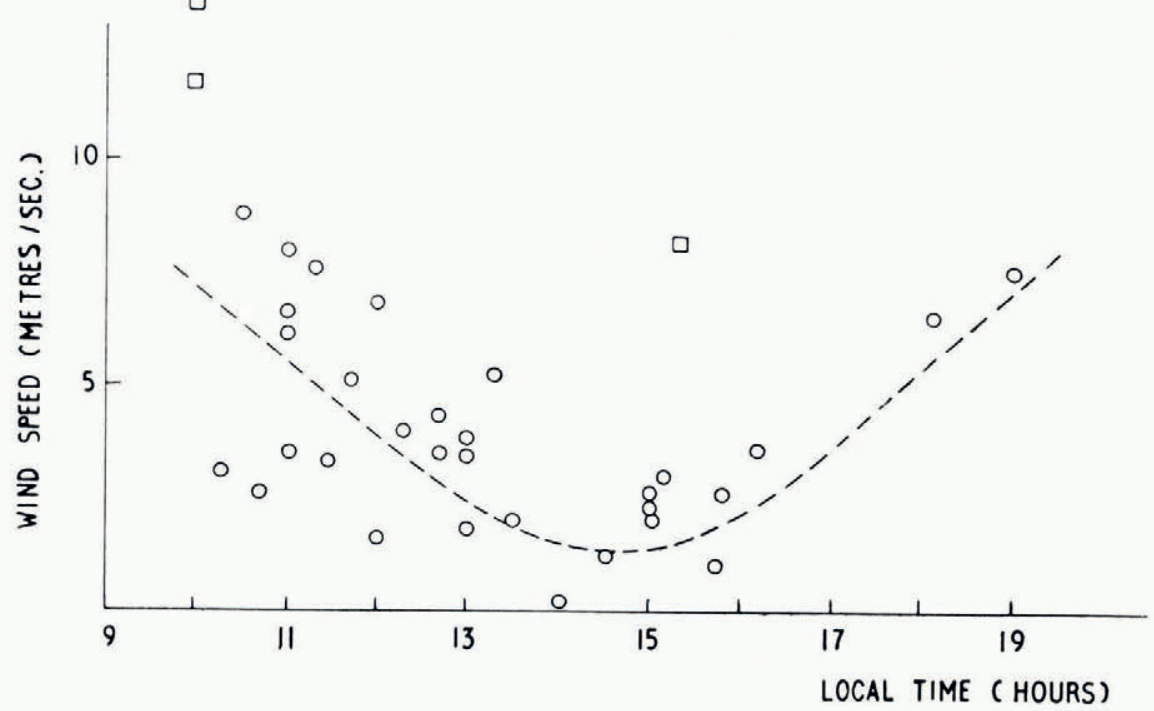
Fig. I2. Wind-speed values at $2 \mathrm{~m}$. plotted against mean time of observation, illustrating the typical decrease in wind during the
afternoon

6-II April I96o; $\square$ I2-13 April 1960

of observations on the mountain, are shown in Table I. There is apparently no obvious decrease in the speed of the main air stream at $14.00 \mathrm{hr}$. as exhibited by the local winds. Wind speeds measured in the morning on the glacier, however, are seen to be of the same order of strength. The strengthening of the wind during 12-14 April on the mountain is reflected in the radiosonde measurements. It is shown in Figure io that the glacier wind did not abate during the afternoon on these three days, and the strong winds appeared to over-ride any local effects.

\section{Short-wave Solar and Sky Radiation Measurements}

Total integrated "short-wave" radiation from sun and sky was measured with a GunnBellani spherical pyranometer, originally described by Gunn and Yeo (I 95I). Radiant energy incident on a blackened brass bulb in an evacuated glass sphere causes distillation of alcohol

TAble I. Wind Speed at $4,876 \mathrm{~m}$.

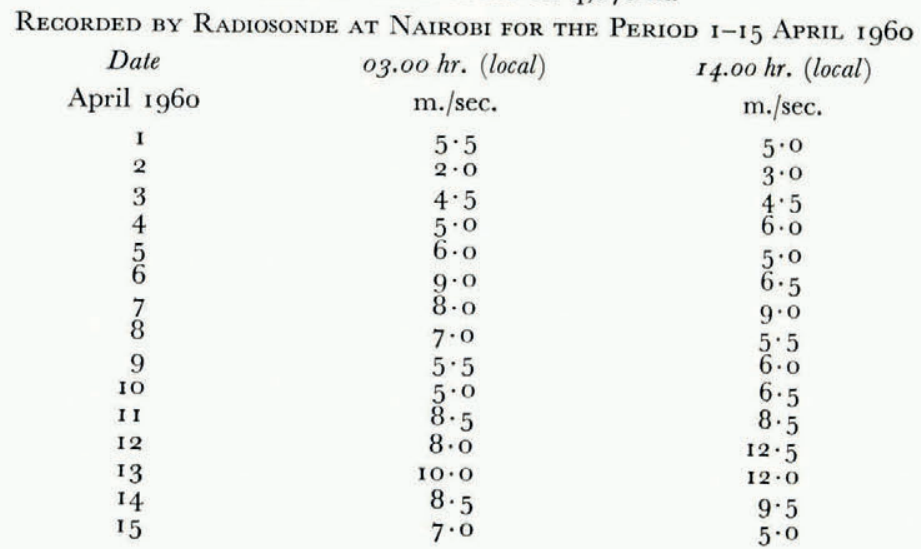


in the bulb into a long graduated glass condenser maintained at ambient temperature. The volume of the alcohol in the condenser is proportional to the total radiation incident in a given period. The instrument is linear over much of its range and accurate to within to per cent. As used sunk in the firn, the ambient temperature of the condenser $\left(0 \cdot 0^{\circ} \mathrm{C}\right.$.) remains conveniently constant. The alcohol level had to be frequently re-set during the day. On several days the bulb was allowed to run dry, so that the record for those days is incomplete.

The relation between total daily short-wave radiation and total number of hours sunshine is shown in Figure I3. Radiation figures are somewhat higher than values given by Bergström for the Ruwenzori. However, thick cloud is more prevalent there than on Mount Kenya.

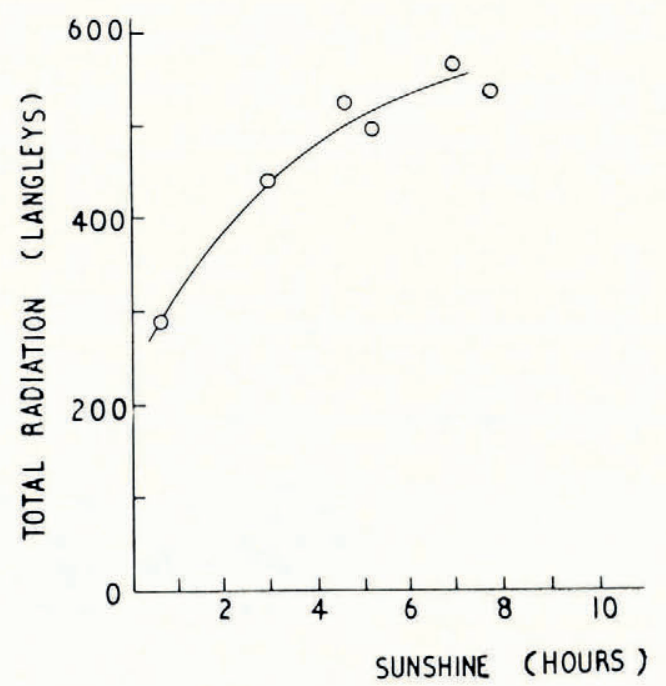

Fig. 13. Total daily radiation (in Langleys) plotted against duration of daily sunshine

Short-wave radiation measurements were also made with a portable solarimeter constructed by Dr. J. G. McCulloch and kindly lent to the author. The solarimeter (Fig. I4) was similar to one described by Monteith (I959). The albedo of the snow surface was determined at different times of the day and over fresh and old snow surfaces. The values were obtained by pointing the solarimeter alternatively upwards and downwards. Table II gives figures for various conditions and also figures for a period between 10.00 and $15.00 \mathrm{hr}$., which give no evidence of any diurnal change in albedo as reported by Hubley (1955, p. 56 I). However, in agreement with him is the high albedo of fresh snow surfaces and during cloudy conditions. For purposes of calculating radiation absorbed at the glacier surface, a value of 70 per cent has been used for all periods.

\section{Calculation of Net Long-wave Radiation at the Surface}

The net long-wave radiation is the difference between outgoing radiation from the snow surface, which acts approximately like a black body at these wave-lengths, and incoming radiation from the sky. Values for clear sky conditions were estimated using an Elsasser radiation chart (Elsasser, 1942) and the effective precipitable water-path length between different heights above the surface. The latter were obtained from average figures compiled by the Meteorological Department (East African Meteorological Department, ig6o) for the humidity mixing ratio for April at heights of 500, 400, 300 and $200 \mathrm{mb}$. pressure levels. The pressure at glacier level is about $55^{\circ} \mathrm{mb}$. This method gave a mean effective water-path 
length of $0.28 \mathrm{~cm}$. From a standard Elsasser chart this gives a figure of $0.297 \mathrm{Ly} / \mathrm{min}$. of radiation from a clear sky. Assuming that the snow surface radiates as a black body at $273^{\circ} \mathrm{K}$., the outgoing radiation is $0.459 \mathrm{Ly} . / \mathrm{min}$. and therefore the net radiation, which is outgoing, is $0.162 \mathrm{Ly} . / \mathrm{min}$. However, Robinson (I950) has stated that the Elsasser chart gives a figure which is too high for back radiation. Using the curve given by Robinson showing the magnitude of error with temperature, the back radiation has been adjusted to $0.250 \mathrm{Ly}$. $/ \mathrm{min}$., giving a net outgoing figure of $0 \cdot 209 \mathrm{Ly} . / \mathrm{min}$.

Cloudy or partly cloudy conditions also have a marked effect on the net outgoing radiation. Here again it has been necessary to rely on an empirical method of calculation given by Sverdrup (1935, p. 147).

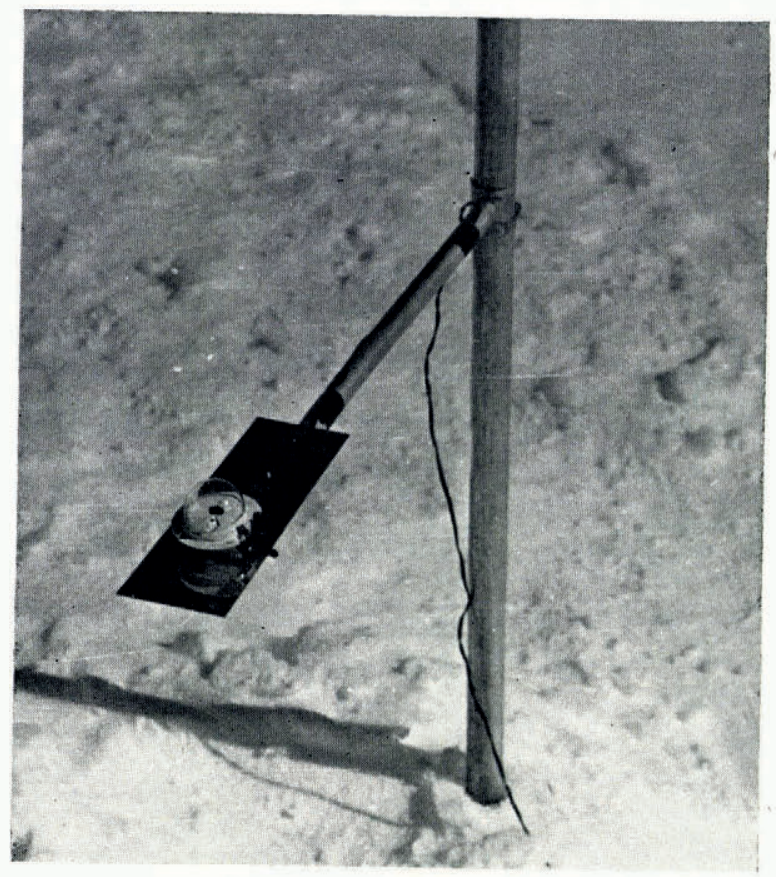

Fig. I4. Monteith solarimeter fixed to an anemometer mast

Table IIa. Glacier Albedo

Summary of Observations

$\begin{array}{lcc} & \text { Old snow } & \text { New snow } \\ \text { Sunshine } & 62.3 & 69 \cdot 3 \\ \text { Cloud } & 75.8 & 79.5\end{array}$

Table IIb. Glacier Albedo

Observations made above a Fresh Melting Snow Surface at Different Times of Day

$\begin{array}{cc}\text { Time } & \text { Albedo } \\ \text { 10.45 } & 76 \cdot 8 \\ \text { 10.52 } & 70 \cdot 3 \\ 11.55 & 73 \cdot 9 \\ 12.00 & 77 \cdot 4 \\ \text { 12.10 } & 79 \cdot 2 \\ \text { 13.00 } & 72 \cdot 5 \\ \text { 14.00 } & 79 \cdot 1\end{array}$

Remarks

Cloudy

Sunshine

Cloudy

Cloudy

Cloudy

Thick mist

Thick mist and hail 
If $R_{n}$ is the observed net radiation, $R_{\mathrm{o}}$ is the radiation for clear-sky conditions, and $C$ is the cloudiness in tenths,

then

$$
R_{n}=R_{0}(\mathrm{I}-0 \cdot 075 C) .
$$

This formula has only been used for readings taken in Vestspitsbergen where it was in satisfactory agreement, and it is not known how accurate it is under equatorial conditions. Another source of error of unknown magnitude is the possible increase in water vapour locally over the mountain due to the upsurge of air streams over the mountain. This would tend to increase the back radiation and hence decrease the net outgoing radiation.

\section{Ablation and Accumulation at the Surface}

Ablation and accumulation were measured in terms of lowering or raising of the snow surface. The reference mark was a cord stretched tightly between two aluminium stakes and knotted in the middle. The distance from the cord to a glass slide lying parallel to the surface was measured. Another cord was stretched to a further stake and used as a check reference. The method was similar to the one used by Adkins (1958, p. 200). The stakes were hammered $50 \mathrm{~cm}$. into the firn, which appeared to eliminate any settling due to radiation heating. Accumulation occurred mainly during the night, but for those periods when it occurred during the day the method obviously measures the difference between the accumulation and ablation. However, daytime accumulation occurred mainly during cold cloudy weather, when little ablation would be taking place. Furthermore, ablation would tend to be inhibited due to re-freezing of the surface.

Density measurements were made on different occasions and on layers of snow near the surface. Hence the accumulation and ablation in terms of centimetres of water could be calculated. Figure i 5 shows the daily and net values of accumulation and ablation for the period 6-I5 April. Accumulation only is shown on 5 April. The resultant balance for the period was $3.8 \mathrm{~mm}$. accumulation.

Samples of old compacted snow had densities ranging from 0.4 to $0.5 \mathrm{~g} . / \mathrm{cm} .{ }^{3}$ but more typically $0.4 \mathrm{~g} . / \mathrm{cm} .^{3}$. The density of fresh snow ranged from $0.2 \mathrm{I}$ to $0.32 \mathrm{~g} . / \mathrm{cm}{ }^{3}$. It was of the needle variety and was similar in density to snow composed of needle crystals reported on Blue Glacier, Washington, by LaChapelle (1959[a]). For purposes of calculating ablation figures, mean densities of $0 \cdot 40$ and $0.25 \mathrm{~g} . / \mathrm{cm} .{ }^{3}$ were taken for old and new snow, respectively.

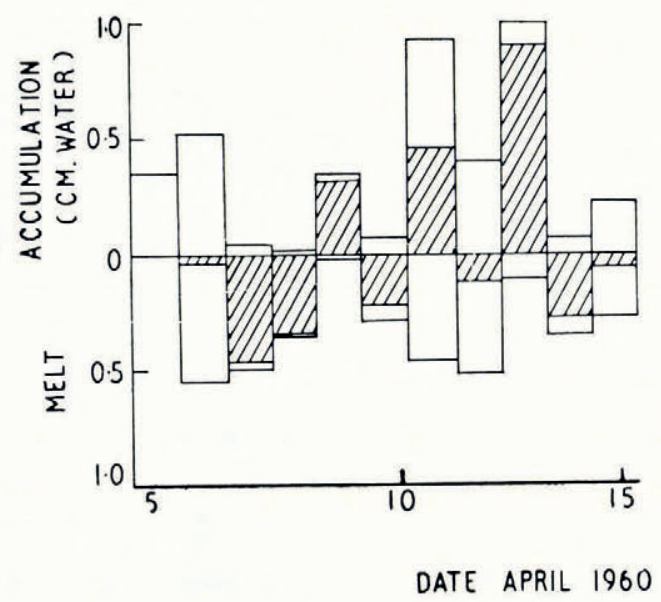

Fig. I5. Daily values of accumulation and ablation (cm. water-equivalent). The hatched area represents net loss or gain 


\section{Heat Exchange in the Glacier Surface Layers}

This section describes calculations of the heat exchange and heat balance at the glacier surface during certain periods in which the measurements described previously were made in detail. During all the periods considered melting was taking place, either spasmodically or continuously. At times there may have been a deficit of heat directly at the surface, causing a slight fall in temperature below $0^{\circ} \mathrm{C}$. This is taken into account where necessary, but the glacier generally is assumed to be in a state of isothermal melting with no appreciable heat conducted to or from layers deep beneath the surface. The glacier receives heat from the following sources:

(I) Short-wave radiation.

(2) Long-wave atmospheric radiation.

(3) Turbulent transfer from the air when the temperature gradient is positive.

(4) Condensation of water vapour when specific humidity increases with height.

It also loses heat from:

(I) Long-wave radiation emitted by the surface.

(2) Turbulent transfer to the air when the temperature gradient is negative.

(3) Evaporation of water vapour when the specific humidity decreases with height.

It is known from measurements at other localities that solar radiation penetrates below the surface and to take this into account a rough model has been used for calculations. This model assumes that solar radiation penetrates to a depth determined by a mean absorption coefficient for the snow layers but that long-wave emission takes place from the surface layer, assumed to be $2 \mathrm{~cm}$. thick, and that turbulent exchange and water-vapour transport also take place from this layer. As will be seen, the model is useful in explaining the fact that appreciable melt occurs during certain periods, even when there is an apparent heat deficit in the surface. This is then assumed to be due to radiation which has penetrated below the $2 \mathrm{~cm}$. surface layer and melting actually occurs below this layer. The calculation is now treated in greater detail. The $2 \mathrm{~cm}$. layer is defined here as the "surface layer".

\section{(a) Radiation}

(i) Short-wave radiation. If $I$ is the intensity of incident short-wave radiation and $\alpha$ is the snow albedo, then

$$
I_{n}=I(\mathrm{I}-\alpha)
$$

will penetrate the surface. If $a \mathrm{~cm} .^{-1}$ is the mean absorption coefficient of the glacier surface layers over all relevant wave-lengths of radiation, then

$$
I_{2}=I_{n} e^{-2 a} \text {, }
$$

where $I_{2}$ is the intensity of radiation at a depth of $2 \mathrm{~cm}$. and an amount

$$
I_{s}=I(\mathrm{I}-\alpha)\left(\mathrm{I}-e^{-2} a\right)
$$

is absorbed in the surface layer. The radiation $I_{d}$ absorbed below the surface layer is given by $I_{d}=I_{2}$. No measurements of $a$ were made and for purposes of calculation it was necessary to deduce mean values from measurements made by Gerdel (1948), Liljequist (1957) and Thomas ( 1963 ) in other localities. The absorption coefficient varies with snow density. Values agree at the low snow densities $\sim 0.25 \mathrm{~g} . / \mathrm{cm} .{ }^{3}$ and they appear to decrease linearly with increasing density but with different slopes, so that Gerdel's figure at a density of $0.4 \mathrm{~g} . / \mathrm{cm} .{ }^{3}$ is $0.1 \mathrm{~cm} .^{-1}$, whereas Thomas's figure is $0.22 \mathrm{~cm} .^{-1}$. A mean value of $a=0.28 \mathrm{~cm}$. $^{-1}$ for "new" snow with a mean density of $0.25 \mathrm{~g} . / \mathrm{cm} .^{3}$, and $a=0.2 \mathrm{~cm} .^{-1}$ for "old" snow with a mean density of $0.4 \mathrm{~g} . / \mathrm{cm} .{ }^{3}$ was used. The angle of incidence of solar radiation was taken into account when estimating vertical penetration depths. 
(ii) Long-wave radiation. The method of estimating long-wave radiation has already been given. Water and ice are known to have very high absorption coefficients for the wave-lengths concerned. Goody (1964, p. 415) has quoted figures of the order of $1 \mathrm{IO}^{2}-\mathrm{IO}^{3} \mathrm{~cm} \mathrm{~cm}^{-1}$. Hence radiation will be emitted close to the surface. Due to the grainy nature of the snow, some grains to a depth of $\sim_{\mathrm{I}-2} \mathrm{~cm}$. will be exposed to the surface.

\section{(b) Turbulent transfer from the atmosphere}

It is assumed, following Elliot (1964, p. 264), that vertical heat flux due to turbulent motion is independent of height during the daytime up to the $4 \mathrm{~m}$. height considered in these calculations.

The transfer $Q_{A}$ at a height $z$ above the surface is given by

$$
Q_{A}=\rho C_{p} K_{H} \partial \theta / \partial z
$$

where $\rho$ is the air density, $C_{p}$ the specific heat, $K_{H}$ the eddy diffusivity and $\partial \theta / \partial z$ the gradient of potential temperature. $K_{H}$ is given by $K_{H}=k^{2} z^{2} \partial u / \partial z$, where $\partial u / \partial z$ takes on the form of equation (I).

On the majority of occasions analysed conditions were stable with fully forced convection. Equation (7) has also been applied to two periods when conditions were unstable. Also, neutral conditions have been assumed to further simplify the calculations. The daytime inversions were small and the wind gradient not far from the neutral form. The term $\partial \theta / \partial z$ and hence $Q_{A}$ is expected to be small below the surface $2 \mathrm{~cm}$.

\section{(c) Water-vapour transfer}

Whether water-vapour transfer occurs towards or away from the surface depends on whether the water-vapour content of the air increases or decreases respectively with height. Near the surface, the vapour pressure serves as a close substitute for the specific humidity. The water vapour $E$ transported from the surface in $\mathrm{g} . \mathrm{cm}^{-2} \mathrm{sec}^{-1}$ has been estimated from the equation:

$$
E=-0.623 \rho u_{z} C_{z}\left(e_{z}-e_{0}\right) / P,
$$

where $u_{z}$ and $e_{z}$ are wind speed and water-vapour pressure at a height $z, e_{0}$ is the vapour pressure at the surface (assumed saturated value at $0 \cdot 0^{\circ} \mathrm{C}$. when melting is occurring), $C_{z}$ is a drag coefficient assumed equal to $0 \cdot 003^{2}$ and $P$ is the atmospheric pressure. In spite of the relatively high daytime humidity (Fig. 7), the low temperatures ensured low water-vapour concentration and in all periods considered $e_{z}-e_{0}$ was negative and evaporation occurred. It can be seen that $E$ will be small on entering the surface, because $u$ will be small.

\section{(d) Calculation of the snow melt}

(i) The surface layer. The "surface layer" has been defined previously as a layer $2 \mathrm{~cm}$. thick directly below the surface. The net heat $Q_{s}$ absorbed in the surface layer is given by

$$
Q_{s}=I_{s}-R_{n}+Q_{A} \text {. }
$$

Now, the calculated heat removed by evaporation equals $600 E$. If $600 E>Q_{s}$, then evaporation cannot occur at this rate and equation (8) cannot apply. This means, in effect, that there is insufficient heat to maintain a free water surface due to re-freezing caused by evaporation, and the air immediately above the surface will not be saturated. In these cases, it is assumed that $Q_{s}=600 E^{\prime}$, where $E^{\prime}$ is an effective evaporation rate depending directly on $Q_{s}$. (As mentioned previously, only evaporation occurred during each period analysed. Of course, if condensation occurred at a rate $E$, then $Q_{s}{ }^{\prime}=Q_{s}+600 E$. Further, during no period did conditions appear right for sublimation and this process has been neglected.) Then, if $h_{s}$ is the amount of ice melted (in cm. water-equivalent) in the surface layer and $h_{e}$ is the amount evaporated, 
then

$$
\begin{aligned}
& \left.\begin{array}{rl}
80 h_{s} & =Q_{s}-600 E \\
h_{e} & =E
\end{array}\right\} \quad Q_{s}>600 E, \\
& \left.\begin{array}{l}
h_{s}=0 \\
h_{e}=E^{\prime}
\end{array}\right\} \quad Q_{s}=600 E^{\prime}, \quad E^{\prime}<E .
\end{aligned}
$$

(ii) Below the surface layer. The heat absorbed below the surface layer is assumed to be $I_{d}$, given by equation (5). Then

$$
h_{d}=I_{d} / 80 .
$$

The only exception to this is when $Q_{\delta}$ is negative, no evaporation can occur, and it is assumed heat is transferred upwards to the surface layer by conduction and radiative diffusion.

(iii) Total melt. The total melt $H$ is given by

$$
H=h_{s}+h_{e}+h_{d} .
$$

\begin{tabular}{|c|c|c|c|c|c|c|c|c|c|}
\hline $\begin{array}{c}\text { Date } \\
\text { April } 1960\end{array}$ & Time & $\begin{array}{c}I \\
\text { Ly. }\end{array}$ & $\begin{array}{l}I_{n} \\
\text { Ly. }\end{array}$ & $\begin{array}{l}R_{n} \\
\text { Ly. }\end{array}$ & $\begin{array}{r}\theta_{2.0} \\
{ }^{\circ} \mathrm{C} .\end{array}$ & $\begin{array}{c}u_{2.25} \\
\text { m./sec. }\end{array}$ & $\begin{array}{c}e_{1.5} \\
\mathrm{~mm} . \mathrm{Hg}\end{array}$ & $\begin{array}{l}Q_{A} \\
\text { Ly. }\end{array}$ & $\begin{array}{c}600 E \\
\text { Ly. }\end{array}$ \\
\hline 6 & I I.07-1 I. $4^{2}$ & 48 & $14 \cdot 4$ & $5 \cdot 0$ & $0 \cdot 0$ & $3 \cdot 3$ & $3 \cdot 2$ & o & \\
\hline 6 & $14.5^{0}-15.45$ & 26 & $7 \cdot 7$ & $4^{\circ}$ & 0.7 & & & $2 \cdot 3$ & \\
\hline 7 & $1 \mathrm{II} .20-12.20$ & & & & -0.6 & $6 \cdot 2$ & I. & $-3 \cdot 2$ & \\
\hline & $12.20-13.20$ & 208 & $62 \cdot 4$ & $28 \cdot 4$ & $I \cdot I$ & $5 \cdot 0$ & 2 . & $4 \cdot 3$ & \\
\hline 7 & $\begin{array}{l}13.20-14.45 \\
14.45-16.45\end{array}$ & & & 18.2 & $\begin{array}{l}1 \cdot 1 \\
1 \cdot 2\end{array}$ & $\begin{array}{l}3 \cdot 4 \\
2.0\end{array}$ & $\begin{array}{l}3.6 \\
3.6\end{array}$ & 4. & \\
\hline 8 & $11.55^{-15} .00$ & $\begin{array}{l}163 \\
\end{array}$ & 48.9 & $12 \cdot I$ & $\begin{array}{l}1.3 \\
1 \cdot 3\end{array}$ & & & $\begin{array}{l}4 \cdot 3 \\
8 \cdot 9\end{array}$ & $\begin{array}{l}2 . \\
2 .\end{array}$ \\
\hline I0 & $11.05^{-16.50}$ & 222 & $66 \cdot 6$ & 23 . & 0.7 & $4 \cdot 8$ & $3 \cdot 8$ & 16.6 & 15. \\
\hline II & $10.15^{-1} 3.1$ & I69 & $50 \cdot 7$ & 12 . & 0.0 & & & $0 \cdot 0$ & \\
\hline I3 & $11.15-12.10$ & 82 & $24 \cdot 6$ & $6 \cdot 4$ & $-1 \cdot 3$ & $12 \cdot 0$ & $2 \cdot 9$ & $-1 \mathrm{I} \cdot 5$ & 3. \\
\hline
\end{tabular}

Table III. Observations of Radiation, Temperature, Wind Speed, Humidity and Calculated

$$
\text { Turbulent Exchange and Evaporation }
$$

Table IV. Deduced Values in Heat Balance, Calculated Melt and Measured Melt (The numbers in brackets correspond to those in Table III.)

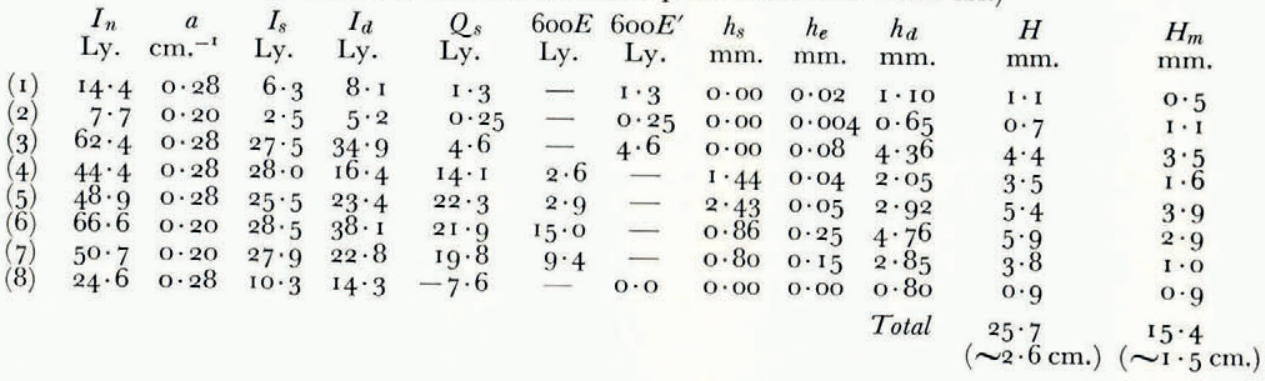

The quantities involved in calculating numerical values for equations (9) to (I3) are shown in Tables III and IV. In Table IV the measured value of melt $H_{m}$ is compared with the calculated value $H$. Table VI gives a few periods when data were incomplete and $H_{m}$ is compared with

$$
H_{I}=\frac{I_{n}-R_{n}}{80} \text {. }
$$

(iv) Percentage contribution to $H$ of different meteorological factors. Table $\mathrm{V}$ shows the percentage contribution of radiation $\left(h_{I}\right)$, turbulent exchange $\left(h_{Q}\right)$ and evaporation $\left(h_{e}\right)$ towards $H$. It is assumed that the heat of evaporation is drawn equally from $I_{s}{ }^{\prime}$ and $Q_{A}$, except $600 E / 2>I_{s}{ }^{\prime}$ or $Q_{A}$. Then it is assumed that $600 E=\left(I_{s}{ }^{\prime}\right.$ or $\left.Q_{A}\right)+f\left(Q_{A}\right.$ or $\left.I_{s}{ }^{\prime}\right),\left(I_{s}^{\prime}=I_{s}-R_{n}\right)$. 
Table V. Pergentage Melt due to Radiation $\left(h_{I}\right)$, Turbulent Exghange $\left(h_{Q}\right)$ and Evaporation $\left(h_{e}\right)$

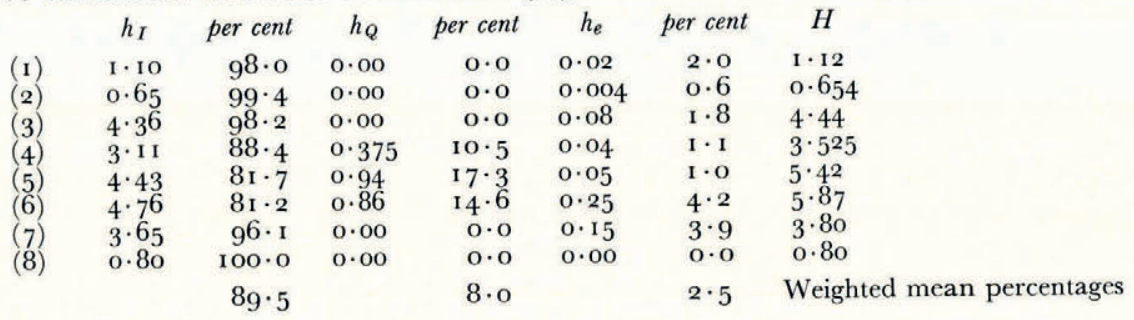

\section{(e) Interpretation of results}

On the average, $H_{m}$ is in agreement with $H$ to 40 per cent, which is within the estimated error in the calculations and measurements $\sim 50$ per cent. The model gives good agreement on 13 April (period 8). At this time there were negative air temperatures and strong winds, and a calculated loss of heat at the surface. However, the measured melt can be accounted for satisfactorily by sub-surface melting. A simple calculation of $H$ from the formula $I_{n}-R_{n}+Q_{A}-600 E$, disregarding sub-surface effects, gives good agreement for periods when there was a positive surface balance, but not for times such as period 8 . The results given in Table VI for 12 and 14 April were during similar weather to I 3 April, and the large $H_{m}$ again depends on melting at depth. It cannot be said with complete confidence, however, that this is the whole explanation, and further confirmatory results are needed.

Table VI. Measured Melt $\left(H_{m}\right)$ Compared with Calculated Melt $\left(H_{I}\right)$ from Net Radiation only, for Periods when Other Quantities were not Available

$\begin{array}{ccccc}\begin{array}{c}\text { Date } \\ \text { April I960 }\end{array} & \text { Period } & \left(I_{n}-R_{n}\right) & \begin{array}{c}H_{I} \\ \mathrm{~mm} .\end{array} & \begin{array}{c}H_{m} \\ \mathrm{~mm} .\end{array} \\ \text { I2 } & \text { 11.30-14.00 } & 38 \cdot 2 & 4 \cdot 8 & 3 \cdot 0 \\ \text { I2 } & 15.15-17.00 & 17 \cdot 4 & 2 \cdot 2 & 1 \cdot 7 \\ \text { I4 } & \text { 14.10-16.15 } & 21 \cdot 8 & 2 \cdot 7 & \mathrm{I} \cdot 6 \\ \text { 15 } & \text { 11.00-12.00 } & 17 \cdot 5 & 2 \cdot 2 & \mathrm{I} \cdot \mathrm{I} \\ \text { I5 } & 12.00-13.00 & 11 \cdot 9 & 1 \cdot 5 & \mathrm{I} \cdot 6\end{array}$

It is seen that $H_{m}$ is consistently lower than $H$ for periods 3 to 7 in Table IV and most periods in Table VI. The most likely explanation is the error in estimating the density of the snow, as described earlier. Measurements were made at the beginning and end of the ablation periods. Because of melting at depth and the uneven melting of any layer, the snow surface becomes pitted and irregular, and hence the density of the surface layer may initially become less during a day's melt (LaChapelle, r 959 [b]).

The most significant features of Table $\mathrm{V}$ are the expected large contributions of radiation to the total melt and the very small contribution of evaporation. It appears that evaporation is more effective in inhibiting ablation, as the amount of heat extracted by this process from the surface layer is appreciable. Heat gained by turbulent exchange from the air is often apparently used up in the evaporation process but in certain afternoon periods it can cause up to nearly 20 per cent of the total melt.

Pitting of the snow and uneven collapse due to sub-surface melting of random grains may hasten the initial formation of penitentes. Although these do not appear to develop on Lewis Glacier, they grow to a large size on the higher Kilimanjaro glaciers. At the higher altitude of these glaciers there will be a greater heat deficit in the surface layers and therefore subsurface melting may be important. It is conceivable that later growth could be explained in these terms. If all material is removed from the pits by evaporation, as suggested by some authors, then the growth of penitentes must be very slow.

It is well known that ice bands form below the glacier surface in fresh snow and these have been observed by both Charnley and the author. These are probably formed by sub-surface 
melting, the water being re-frozen in the cold wave of the following night. This suggestion has been made previously by Liljequist (1956, p. I03). They have been observed a few centimetres below the surface. Once formed, more water will collect above the band and it will thicken with time. As the snowpack becomes older it will compact and become more transparent. A rough calculation shows that only a small amount of any one layer will be melted on any particular day and this is likely to be re-frozen in the night cold wave. Measurements made by the author on a previous expedition in January I 960 of the temperature distribution to a depth of $30 \mathrm{~cm}$. in a fresh snowpack are shown in Figure 16 . Observations were made with an accurate mercury thermometer lowered into narrow holes in the snow.

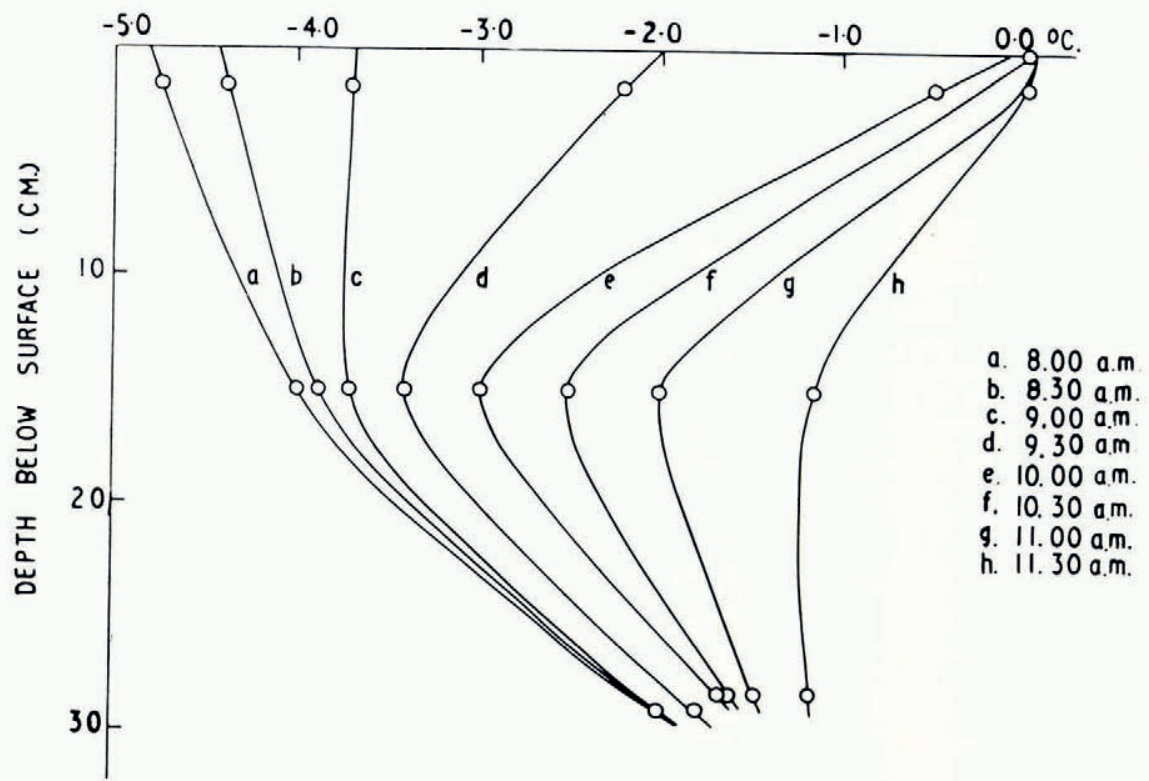

Fig. I6. Temperature profiles beneath a fresh snow surface for selected times from o8.oo to II. 30 hr. on a clear morning with bright sunshine

Curve (a) shows that the cold wave had penetrated to at least $30 \mathrm{~cm}$. and melting will not occur much below this level during the day. Not much melt water will penetrate downwards before being re-frozen and in any case it will be arrested by ice bands. Hence, only the top $30 \mathrm{~cm}$. or so will compact from the intervention of melting and layers underneath will compact under their own weight. However, free water has been found by the author and Charnley at a depth of about $30 \mathrm{~cm}$. apparently collected on an ice band. The observed outflow from the glacier is probably due to water flowing down these ice bands and eventually finds its way through cracks and crevasses.

The temperature-depth curves of Figure 16 also illustrate the warming of the sub-surface layers under conditions of light wind and bright sun. The observed rates of warming at the three depths can be accounted for roughly by employing the model used in the previous calculations.

\section{Conclusion}

The main conclusion drawn is that, at least in the middle reaches of the glacier, radiation is easily the largest agent of ablation (as predicted), accounting for about go per cent of the observed melt. The mean weighted percentage in Table $\mathrm{V}$ may be compared with two of those quoted by Adkins ( $195^{8}$, p. 204) for other regions. On Fröya Gletscher (lat. $74^{\circ} 24^{\prime}$ N., long. 
$20^{\circ} 50^{\prime}$ W.) at $453 \mathrm{~m}$. altitude in August, radiation accounted for 8.2 per cent, turbulent exchange 83.4 per cent and evaporation 8.4 per cent. The equivalent figures for Salmon Glacier (lat. $56^{\circ} \mathrm{Io}^{\prime} \mathrm{N}$., long. $\mathrm{I}_{30^{\circ}} \mathrm{o} 7^{\prime} \mathrm{W}$.) at $\mathrm{r}, 700 \mathrm{~m}$. altitude were respectively $74 \cdot 7$, I 5.4 and 9.9 per cent.

Melting appears to continue throughout the accumulation season and on seven days out of ten measured ablation exceeded accumulation. However, as pointed out earlier, i96o appeared to be a poor accumulation season.

Meteorological observations indicated conditions not unlike those encountered by the 1957-58 expedition in the early part of an ablation season, and it is the author's experience that climatic conditions differ little over the whole year. This is borne out by Figure 3 . However, large amounts of accumulation, usually from 30 to $100 \mathrm{~cm}$., can only be expected during the rainy seasons. The $30 \mathrm{~cm}$. of new snow encountered when the expedition reached Lewis Glacier in early April i96o probably collected during three or four heavy falls but no further heavy falls were experienced. Normally, appreciable accumulation would be expected during April.

It is apparent that evaporation can never contribute more than a few per cent to the total ablation, although the percentage may be greater on higher reaches of the glacier. Turbulent exchange may have more effect on the lower reaches near the snout. The strong up-currents experienced bring warm air to the area near the snout and it would be interesting to make air-temperature measurements there.

The actual magnitude of the ablation on the firn field is comparatively small and the daily ablation period only lasts from about i 1.00 to $17.00 \mathrm{hr}$. Thus the annual turnover both of ablation and accumulation would appear to be small compared with that on temperate glaciers.

It is more difficult to explain the steady recession of the glaciers this century (Charnley, 1959) from the results obtained. It seems unlikely that the heat balance could have changed appreciably during the last half century and it seems more likely to be due to an accumulation deficit. However, the laying bare and solar heating of scree and bare rocks by the recession of the snout will cause the currents reaching the snout to become warmer, and hence there will be a continuous eroding effect on the snout from exchange with the air. This is the very point made earlier; that the glacier snout must survive an increasingly warmer environment the lower the snout reaches. Also, increasing amounts of dust will be deposited on the glacier, in turn decreasing the albedo with a consequent increase in solar absorption. Charnley ( 1959 ) has shown that deposition of material is very evident in the dry season. As pointed out by Whittow and others (1963), long-wave incident radiation will be increased considerably near the sides of the glacier due to heating of rocks where there may be net incoming radiation, and this is known to lead to side recession.

Thus, many effects influence the net budget of the glacier and more observations are needed before any firm conclusions can be reached.

\section{Acknowledgements}

The author would like to thank the Royal Society for the opportunity to carry out this research. He is greatly indebted to the other members of the team, particularly Mr. P. Wurzel, who carried out the programme of general meteorological observations, Mr. A. Landra, who assisted with some of the observations, and to Dr. I. S. Loupekine for his advice and encouragement.

The author would also like to thank the East African Meteorological Department for generous loans of equipment, and Dr. J. G. McCulloch of the East African Agricultural and Forestries Research Organization for loans of equipment, and also for valuable discussions.

\section{MS. received 17 September 1965}




\section{REFERENCES}

Adkins, C. J. 1958. The summer climate in the accumulation area of the Salmon Glacier. Fournal of Glaciology,
Vol. 3 , No. 23, p. 193-206. Bergström, E. 1955. British Ruwenzori Expedition, r 952 : glaciological observations - preliminary report. Journal
of Glaciology, Vol. 2, No. 17, p. 468-76. Charnley, F. E. p. $480-92$. Church, J. E. 1953. Further on the evaporation and melting of snow at high altitudes. Fournal of Glaciology, Vol. 2, No. I 3, p. 233-35. [Letter.]

East African Meteorological Department. 1960. Upper air data for Nairobi. Summaries of radio-sonde observations of temperature and humidity and of radar wind measurements at standard pressure levels. 1948-55. Nairobi, East African
Meteorological Department. Elliot, W. P. I 964 . The height variation of vertical heat flux near the ground. Quarterly fournal of the Royal
Meteorological Society, Vol. 9o, No. 385, p. $260-65$.

Elsasser, W. M. 1942. Heat transfer by infra-red radiation in the atmosphere. Harvard Meteorological Studies, No. 6. Gerdel, R. W. 1948. Penetration of radiation into the snow pack. Transactions. American Geophysical Union, Vol. 29,
No. 3, p. $366-74$.

Goody, R. M. 1964. Atmospheric radiation. I. Theoretical basis. Oxford, Clarendon Press. Gunn, D. L., and Yeo, D. 1951. The Bellani spherical pyranometer. Quarterly fournal of the Royal Meteorological
Society, Vol. 77, No. 332, p. 293-302.

Howell, W. E. I953. Some measurements of ablation, melting and solar absorption on a glacier in Peru. Transactions. American Geophysical Union, Vol. 34, No. 6, p. 883-88.

Hubley, R. C. I955. Measurements of diurnal variations in snow albedo on Lemon Creek Glacier, Alaska. Journal of Glaciology, Vol. 2, No. 18, p. 560-63.

LaChapelle, E. R. I 959[a]. Annual mass and energy exchange on the Blue Glacier. Fournal of Geophysical Research, Vol. 64 , No. 4, p. 443-49.

LaChapelle, E. R. 1959[b]. Errors in ablation measurements from settlement and sub-surface melting. Fournal of Glaciology, Vol. 3 , No. 26, p. 458-67.

Liljequist, G. H. 1956. Energy exchange of an Antarctic snow-field. Short-wave radiation (Maudheim, $\left.71^{\circ} \mathrm{o}^{\prime} \mathrm{S},{ }_{10} 5^{6} 6^{\prime} \mathrm{W}\right)$. Norwegian-British-Swedish Antarctic Expedition, 1949-52. Scientific Results (Oslo, Norsk Polarinstitutt), Vol. 2, Pt. iA, iog p.

Liljequist, G. H. 1957. Energy exchange of an Antarctic snow-field. Surface inversions and turbulent heat transfer (Maudheim, $\left.71^{\circ} \mathrm{o3}^{\prime} \mathrm{S}, 1^{\circ} 56^{\prime} \mathrm{W}\right)$. Norwegian-British-Swedish Antarctic Expedition, 1949-52. Scientific Results (Oslo, Norsk Polarinstitutt), Vol. 2, Pt. iD, p. 235-98.

Lliboutry, L. 1954. The origin of penitents. Journal of Glaciology, Vol. 2, No. 15, p. $331-38$

Matthes, F. E. I934. Ablation of snowfields at high altitudes by radiant solar heat. Transactions of the American Geophysical Union, 1934, Pt. 2, p. 380-85.

Monteith, J. L. I959. A solarimeter for field use. Fournal of Scientific Instruments, Vol. 36, No. 8, p. 34 I-46. Odell, N. E. 1941. Ablation at high altitudes and under high solar incidence. American fournal of Science, Vol. 239 ,
No. 5, p. 379-82.

Priestley, C. N. B. 1959. Turbulent transfer in the lower atmosphere. Chicago, University of Chicago Press.

Reid, I. C. 1959. Guide-book to Mount Kenya and Kilimanjaro. Nairobi, Mountain Club of Kenya.

Royal Meteorological Society, Vol. 76 , No. 327, ant estimation of atmospheric radiation. Quarterly Journal of the No. 1o, p. 583 . [Letter.]

Spink, P. C. 583. [Letter. p. $329-37$.

Spink, P. C. 1949. The equatorial glaciers of East Africa. Journal of Glaciology, Vol. 1, No. 5, p. 277-81.

Sverdrup, H. U. 1935. Scientific results of the Norwegian-Swedish Spitzbergen expedition, I934. Part 4. The logical conditions. Geografiska and on the Fourteenth of July Glacier in relation to radiation and meteorological conditions. Geografiska Annaler, Årg. 17, Ht. 3-4, p. I45-66.

Sverdrup, H. U. 1936. Note on the logarithmic law of wind structure near the ground. Quarterly fournal of the
Royal Meteorological Society, Vol. 62, No. 266, p. $46 \mathrm{I}-62$.

Thomas, C. W.

No. 34 , p. $48 \mathrm{r}-84$. Wallén, C. C. 1948. Glacial-meteorological investigations on the Kårsa glacier in Swedish Lappland, I $942-1948$.
Geografiska Annaler, Årg. 3o, Ht. 3-4, p. 451-672.

Ward, W. H. 1952. The glaciological studies of the Baffin Island Expedition, 1950. Part 3: equipment and techniques. Fournal of Glaciology, Vol. 2, No. 12, p. I1 $14-21$. Whittow, J. B. 1960. Some observations on the snowfall of Ruwenzori. Journal of Glaciology, Vol. 3, No. 28,
p. $765-72$.

Whittow, J. B., and others. 1963 . Observations on the glaciers of the Ruwenzori, by J. B. Whittow, A. Shepherd, J. E. Goldthorpe and P. H. Temple. Journal of Glaciology, Vol. 4, No. 35, p. $58 \mathrm{i}-6 \mathrm{i} 6$. 